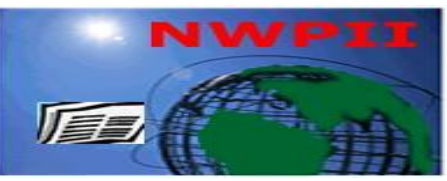

American Journal of Biomedical Sciences

ISSN: 1937-9080

nwpii.com/ajbms

\title{
Evaluation of Analgesic and Sedative-anxiolytic Potential of Paderia foetida Leaf Extract
}

\author{
Mohammad Mustakim Billah ${ }^{1 *}$, Md. Rakibul Hasan ${ }^{2}$, Kashfia Nawrin $^{1}$, Mohiuddin $^{1}$, \\ Md. Razibul Habib ${ }^{3}$
}

${ }^{1}$ Department of Pharmacy, East West University, Dhaka, Bangladesh

${ }^{2}$ Department of Pharmacy, North South University, Dhaka, Bangladesh

${ }^{3}$ Superintendent of Drugs, Directorate General of Drug Administration, Bangladesh

* Corresponding Author

Mohammad Mustakim Billah

Department of Pharmacy

East West University

Dhaka, Bangladesh.

Cell: +8801671079917

Email: mustakimbillah@hotmail.com

Received: 10 March 2015; | Revised: 18 May 2015; | Accepted: 10 June 2015

\begin{abstract}
Thousands of plants are in medicinal use in Bangladesh. Paederia foetida L. is one of the most widely used plants among these for different types of ailments. This study was conducted to assess analgesic and neuropharmacological potential of aqueous, ethanol and ethyl acetate extracts of the plant leaf. Analgesic activity was evaluated at the dose of $400 \mathrm{mg} / \mathrm{kg}$ body weight by acetic acid induced writhing and formalin induced persistent pain tests while at the same dose sedative anxiolytic effect was examined by hole cross, open field and elevated plus maze tests on mice. The results showed that the ethanolic extracts significantly inhibit the nociceptive response in both acetic acid and formalin tests. The other two showed mild response. On the other hand, aqueous extract exhibited mild sedative action while rest of the two possess little sedative anxiolytic effect. These extracts of the plant leaf are yet to be explored for their specific mechanisms and absolute uses.
\end{abstract}

Keywords: P.foetida, writhing, biphasic pain, locomotor activity.

\section{Introduction}

Paederia foetida, belonging to the Rubiaceae family, is a climbing, herbaceous, hairy or smooth slender vine. Leaves are ovate to oblongovate, 6 to $10 \mathrm{~cm}$ long, 3.5 to $5 \mathrm{~cm}$ wide, with conspicuous stipules; petioles commonly to $6 \mathrm{~cm}$ (2.4 inch) long; blades entire, oval to linearlanceolate, 2-11 cm (1-4.3 inch) long, hairy or glabrous, often lobed at base; leaves and stems with disagreeable odor, especially when crushed [1]. 
In Bangladesh, poultice of leaves is used to relieve distention and flatulence. Also used in fractures, to increase strength, to increase sperm, in rheumatism, pain, piles, skin allergy and constipation. Crushed leaves are made into pills and taken in case of bloating and indigestion [2]. Chakma tribe uses it to treat joint pain, rheumatism [3]. It is traditionally used for stomach ailments by Garo and Santal tribes in Bangladesh [4]. Local tribal herbalists in the Chakma, Marma and Tripura community of Chittagong hill tracts used the plant against dysentery [5]. It is also reported to be used in indigestion, gout and urinary stone in Jhenaidah District of Bangladesh. The whole plant is used in wound infections and bone fever in Netrokona district. The leaves are cooked and eaten as vegetable for stomach ailments in Garo tribes of Tangail district of Bangladesh. [6]. These widespread ethnomedical uses of the plant acted as the driving force to conduct analgesic and neuropharmacological tests as a little contribution to its evidence of activities.

\section{Materials and Methods}

\subsection{Collection and Identification of Plant Material}

The plant was collected from Forests of Chittagong Hill Tracts (between $21^{\circ} 25^{\prime} \mathrm{N}$ to $23^{\circ} 45^{\prime} \mathrm{N}$ latitude and $91^{\circ} 25^{\prime} \mathrm{E}$ to $92^{\circ} 50^{\prime} \mathrm{E}$ longitude) of Bangladesh in October 2012 when leaves were in their maximum densities. The plant was identified and authenticated by Bangladesh National Herbarium (Accession No. DAB39518).

\subsection{Preparation of plant extract}

The leaves were dried and powdered and about $1,000 \mathrm{~g}$ of this was macerated with water (PFAQ), ethanol (PFET) and ethyl acetate (PFEA) at room temperature for a period of 7 days with occasional shaking and stirring. The whole mixture was filtered and the filtrate thus obtained was concentrated using a rotary evaporator to get a viscous mass. The viscous mass was kept at room temperature under a ceiling fan to get a dried extract (about 10\%).
Animals: Swiss Albino mice of either sex weighing 20-25gm were collected from International Centre for Diarrheal Disease Research, Bangladesh (ICDDR, B) and were housed under standard conditions of temperature $\left(23 \pm 3^{\circ} \mathrm{C}\right)$, relative humidity $(55 \pm 10 \%), 12 \mathrm{hr}$ light/dark cycles and with free access to food (standard laboratory rodent's chow) and water $a d$ libitum at the Laboratory Animal House, Department of Pharmacy, East West University, Bangladesh. The ethical guidelines for the investigation of experimental animals were followed in all tests.

\subsection{Drugs and Chemicals}

Diclofenac Sodium and Diazepam were obtained from Square pharmaceuticals Ltd., Bangladesh. Acetic Acid were obtained from Mark, Germany. Formalin was purchased from $\mathrm{CDH}$, India. All chemicals used were of analytical reagent grade.

\subsection{Grouping of Animals}

For each test performed, albino mice (20-25 g) were divided into five groups each consisting of four animals. First group served as negative control (received $10 \mathrm{ml} / \mathrm{kg}$ body weight distilled water), Second group served as positive control (received standard drug), while the third, fourth and fifth group received PFAQ, PFET and PFEA respectively at the dose of $400 \mathrm{mg} / \mathrm{kg}$ orally.

\subsection{Analgesic Screening}

\subsubsection{Acetic acid-induced writhing test}

In this model, positive control group received standard diclofenac at the dose of 10 $\mathrm{mg} / \mathrm{kg}$ body weight. Test samples and vehicle were administered orally $30 \mathrm{~min}$ before intraperitoneal administration of $0.7 \% 0.1 \mathrm{ml} / 10$ gm acetic acid solution but diclofenac was administered $15 \mathrm{~min}$ before injection of acetic acid. After an interval of $5 \mathrm{~min}$, the mice were observed for specific contraction of body referred to as 'writhing' for the next $20 \mathrm{~min}$ [7]. Reduction in the number of writhes compared to the control groups was considered as evidence of analgesic effect. 


\subsubsection{Formalin induced persistent pain (Biphasic pain)}

Non fasted animals received standard diclofenac $(10 \mathrm{mg} / \mathrm{kg}$ b.w. $)$ and test samples $(400 \mathrm{mg} / \mathrm{kg}$ ) orally in respective groups 1 hour before formalin challenge [8]. $20 \mu \mathrm{l}$ of $5 \%$ formalin was injected into the dorsal lateral surface of the left hind paw and the time spent for licking and biting in seconds by each animal at 5 minute interval is recorded for $30 \mathrm{~min}$ immediately after formalin injection. The first phase refers the sum of time spent for licking and biting in seconds from 0-5 min. the second phase refers the sum of time spent for licking and biting in seconds from 16-30 min.

\subsection{Tests for sedative and anxiolytic activity}

\subsubsection{Hole cross test}

The positive control group received diazepam (1 mg/kg b.w.) [9]. The number of passage of a mouse through the hole of $3 \mathrm{~cm}$ diameter at a height of $7.5 \mathrm{~cm}$ in the partition of the cage was counted for a period of $3 \mathrm{~min}$ at 0 , 30, 60, 90 and 120 min after oral administration of the test drugs and the standard.

\subsubsection{Open field test}

Like hole cross test, animals in positive control group received diazepam ( $1 \mathrm{mg} / \mathrm{kg}$ b.w.). The floor of an open field of half square meter was divided into a series of squares each alternatively colored black and white. The number of squares visited by the animals was counted for $3 \mathrm{~min}$ at $0,30,60,90$, and $120 \mathrm{~min}$ after oral administration of the test drugs and the standard [10].

\subsubsection{Elevated plus-maze (EPM) test}

The EPM apparatus consists of two open arms $(5 \times 10 \mathrm{~cm})$ and two closed arms $(5 \times 10 \times 15$ $\mathrm{cm})$ [11]. 60 minutes after administration of the test drugs, each animal was placed at the center of the maze facing one of the enclosed arms. During the 5-min test period, the number of open and enclosed arms entries, plus the time spent in open and enclosed arms, was recorded. Entry into an arm was defined as the point when the animal places all four paws onto the arm. The procedure was conducted in a sound attenuated room; observations made from an adjacent corner [12, 13].

\subsection{Statistical analysis}

Statistical analysis for animal experiments was carried out using one-way analysis of variance (ANOVA) followed by Dunnett's multiple comparison tests using SPSS 20 for windows. The results obtained were compared with the vehicle control group. $p$ values $<0.05$, 0.01 and 0.001 were considered to be statistically significant.

\section{Result}

\subsection{Acetic Acid Induced Writhing Test}

Table 1 shows the effect of the aqueous, ethanol and ethyl acetate extracts on acetic acid induced writhing model. The ethanolic extract showed a great inhibition $(90.90 \%)$ of writhing which was comparable with the reference drug $(92.30 \%)$.

Table 1: Acetic Acid Induced Writhing Test of $P$. foetida

\begin{tabular}{ccc}
$\begin{array}{c}\text { Group } \\
(\mathbf{N}=5)\end{array}$ & $\begin{array}{c}\text { No. of writhing } \\
(\text { Average } \pm \text { S.E.M) }\end{array}$ & \% inhibition \\
\hline Positive & $2.75 \pm 0.478^{* * * *}$ & 92.30 \\
Negative & $35.75 \pm 3.099$ & 0 \\
PFAQ & $24.875 \pm 3.125^{* *}$ & 30.41 \\
PFET & $3.25 \pm 0.778^{* * *}$ & 90.90 \\
PFEA & $26.75 \pm 1.479^{* *}$ & 25.17 \\
\hline
\end{tabular}

Each value is presented as the mean $\pm \operatorname{SEM}(n=5) .{ }^{*} p<0.05, * * p<0.01, * * * p<0.001$, Dunnett's test compared with control group. Aq (aqueous), EOH (ethanol), EA (ethyl acetate). 
Table 2: Formalin test of $P$. foetida

\begin{tabular}{ccccc}
$\begin{array}{c}\text { Group } \\
(\mathbf{N = 5})\end{array}$ & $\begin{array}{c}\text { Early Phase Licking } \\
\text { Time } \\
\text { (Average } \pm \text { S.E.M) }\end{array}$ & \% inhibition & $\begin{array}{c}\text { Late Phase Licking } \\
\text { Time } \\
\text { (Average } \pm \text { S.E.M) }\end{array}$ & \% inhibition \\
\hline Positive & $41.5 \pm 2.397 * * *$ & 62.94 & $26.25 \pm 1.931 * * *$ & 58.36 \\
Negative & $112 \pm 6.770$ & 0 & $70.5 \pm 1.707$ & 0 \\
PFAQ & $82 \pm 3.53 * *$ & 26.78 & $52.75 \pm 3.010^{* *}$ & 25.17 \\
PFET & $53.25 \pm 8.439 * * *$ & 52.45 & $30 \pm 4.143 * * *$ & 57.44 \\
PFEA & $49.5 \pm 7.973 * * *$ & 55.80 & $39.5 \pm 5.330^{* * *}$ & 43.97 \\
\hline
\end{tabular}

Each value is presented as the mean $\pm \operatorname{SEM}(n=5) .{ }^{*} p<0.05, * * p<0.01,{ }^{*} * * p<0.001$, Dunnett's test compared with control group. Aq (aqueous), EOH (ethanol), EA (ethyl acetate).

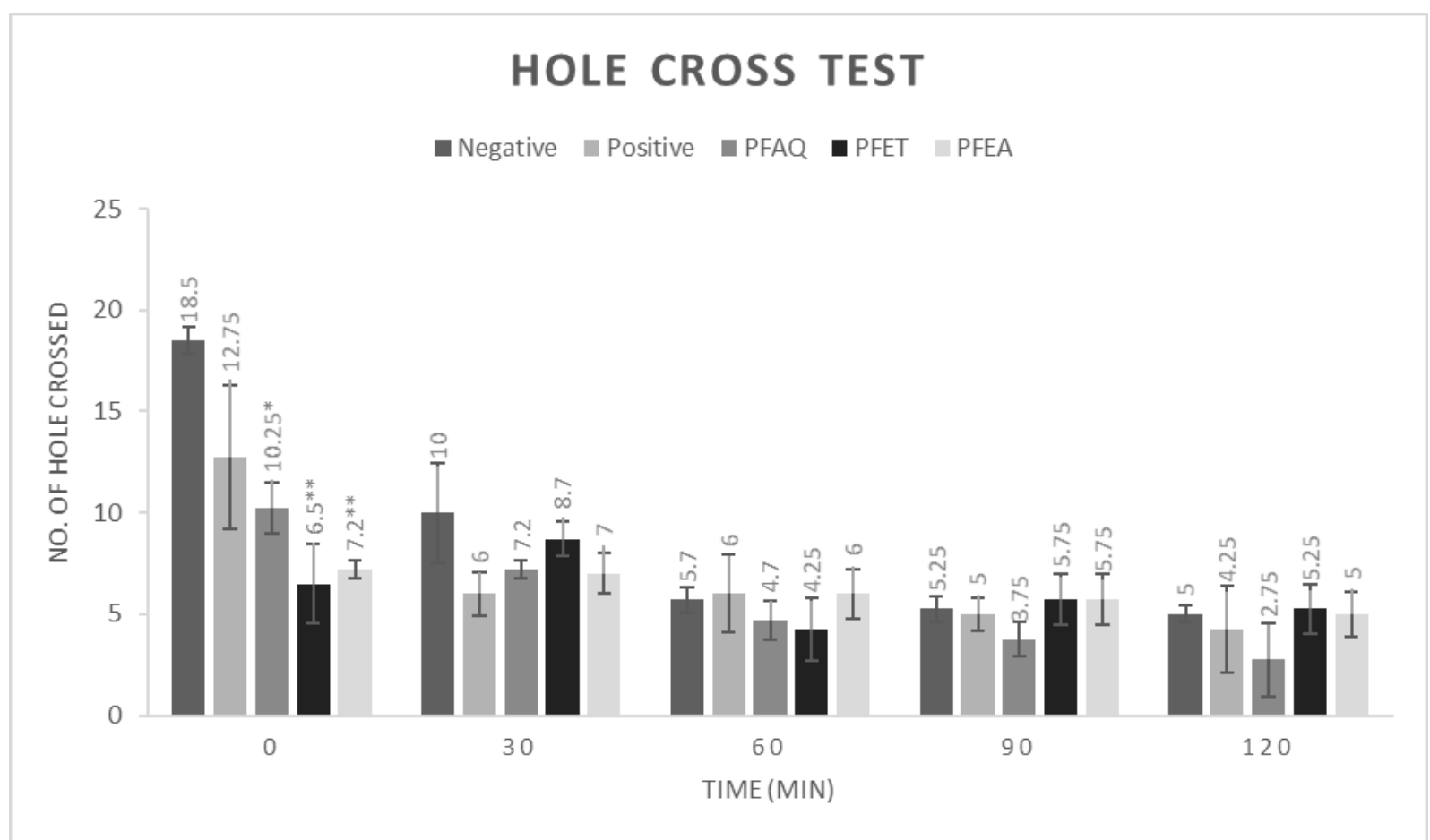

Figure 1: Effect of the aqueous, ethanol and ethyl acetate extracts of leaves of $P$. foetida on hole cross test in mice. Values are mean \pm S.E.M., $(n=4) ; * p<0.05$, *** $p<0.001$ Dunnet test as compared to control (Vehicle $=0.5$ $\mathrm{mL} / \mathrm{mouse})$.

\subsection{Formalin test}

Both ethanol and ethyl acetate extract significantly $(p<0.001)$ suppressed the licking activity in either phase of the formalin-induced pain in mice (Table 2). The reference analgesic also significantly inhibited the licking activity against both phases of nociception.

\subsection{Hole cross test}

The aqueous extract at $400 \mathrm{mg} / \mathrm{kg}$ b.w. oral dose produced a small decrease of locomotion in its initial value during the period of the experiment (Figure 1). Mild suppression of locomotor activity was displayed at last three intervals $(60,90,120 \mathrm{~min})$. 


\subsection{Open field test}

A mild suppression to the number of square travelled by the mice was observed from the $4^{\text {th }}$ and $5^{\text {th }}$ observation period by the aqueous extract of $P$. foetida (Figure 2). The data was statistically significant.

\subsection{EPM test}

The aqueous extract increased the percentage of entries of mice into the open arms and the percentage of time spent in the open arms of the EPM (Table 3).

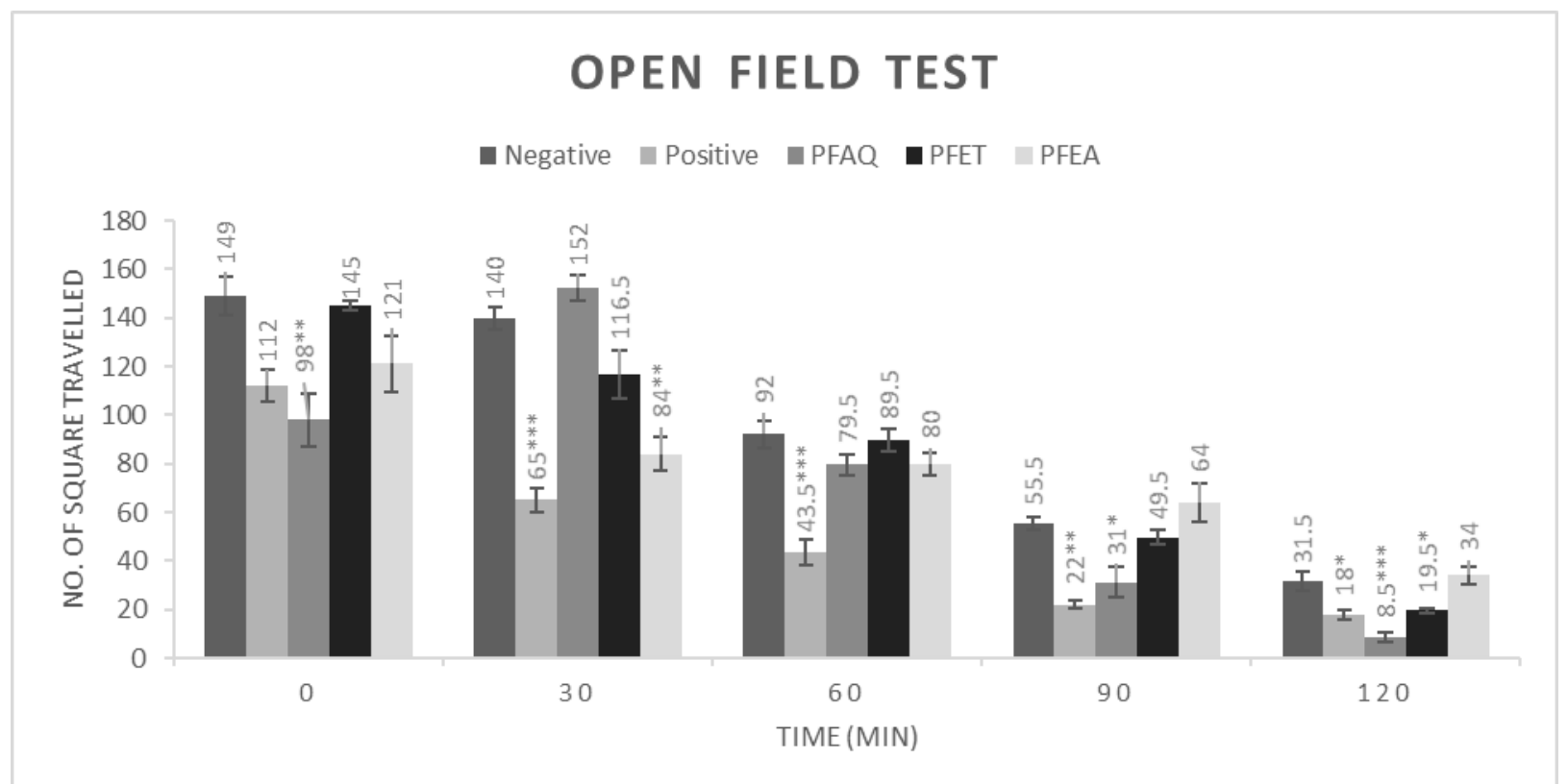

Figure 2: Effect of the aqueous, ethanol and ethyl acetate extracts of leaves of $P$. foetida on hole cross test in mice. Values are mean \pm S.E.M., $(n=4) ; * p<0.05, * * p<0.01$, *** $p<0.001$ Dunnet test as compared to control (Vehicle $=0.5 \mathrm{~mL} /$ mouse).

Table 3: EPM test of $P$. foetida

\begin{tabular}{ccc}
\hline Group (N=5) & $\begin{array}{c}\text { \% no. of entry into the open } \\
\text { arm }\end{array}$ & $\begin{array}{c}\text { \% time spent in the open } \\
\text { arms }\end{array}$ \\
\hline Positive & $76.28 \pm 1.847^{* *}$ & $79.39 \pm 5.749^{* * *}$ \\
Negative & $55.88 \pm 2.133^{* * *}$ & $51.93 \pm 8.243^{* * *}$ \\
PFAQ & $57.12 \pm 0.640$ & $23.05 \pm 5.843^{* *}$ \\
PFET & $49.75 \pm 2.006^{*}$ & $32.83 \pm 3.887^{* *}$ \\
PFEA & $44.62 \pm 2.353^{* * *}$ & $26.26 \pm 5.949^{*}$ \\
\hline
\end{tabular}

Each value is presented as the mean $\pm \operatorname{SEM}(n=5) . * p<0.05, * * p<0.01, * * * p<0.001$, Dunnett's test compared with control group. Aq (aqueous), EOH (ethanol), EA (ethyl acetate).

\section{Discussion}

In acetic acid induced method, pain is generated by prostaglandin via peripheral nociceptive neurons, which are sensitive to both narcotics and non-steroidal anti-inflammatory drugs. The standard drug produced inhibition of writhing movement inhibiting peripheral pain induced by direct action of acetic acid [14]. PFET 
inhibited the acetic acid induced pain with potency compared to the diclofenac sodium.

Formalin test is a well-established valid model for the study of central sensitization events at the spinal level after peripheral inflammatory state [15]. The two distinct phases in formalin test are due to direct effect of formalin on nociception and due to inflammation with the release of serotonin, histamine, bradykinin and prostaglandins and at least to some degree, the sensitization of central nociceptive neurons [16]. Stimulation of opioid receptors has also been suggested as a possible mechanism of action against neurogenic pain [17]. The ability of the extracts to inhibit the second phase of formalininduced pain suggests that it may possess central analgesic activity.

Elevated plus-maze test is used to evaluate psychomotor performance and emotional aspects of rodents. The results showed that $P$. foetida leaf significantly increased the time spent in open arms and decreased the number of entries into closed arms. This type of effect is observed with the drugs that act on GABA benzodiazepine receptor complex as well with drugs that stimulate glucocorticoid production and release in the adrenal cortex [18], after administration of 5HT1B receptor antagonists and 5- HT1A agonists [19]. Therefore with the present data, it is difficult to predict the precise mechanism for the anxiolytic activity of the $P$. foetida leaf.

Locomotor activity refers to an increase in alertness and decrease in locomotor activity considered as sedative effect. The major inhibitory neurotransmitter in the central nervous system is Gamma-amino-butyric acid (GABA). Different types of anxiolytic, muscle relaxant, sedative-hypnotic drugs are shown their action through $\mathrm{GABA}_{\mathrm{A}}$, which imply the extract of $P$. foetida may act by membrane hyperpolarization potentiating GABA-ergic inhibition in the CNS that leads to either decrease in the firing rate of critical neurons in the brain or direct activation of GABA receptor by the extracts [20]. The result indicated that the extract significantly decreased locomotor activity which indicates it has CNS depressant activity.
On extraction of the leaf of $P$. foetida, mixture of fatty acids including non-ionic, capric, lauric, myristic, arachidic and palmitic acids, carotenes and vitamin $\mathrm{C}$ are expected to be isolated in aqueous, ethanol and ethyl acetate fractions. Different types of Essential oil and fatty acids were found to be ligands for the $\mathrm{GABA}_{\mathrm{A}}$ receptors in the central nervous system; which indicates that they act as benzodiazepine-like molecules.

\section{Conclusion}

Analgesic and neuropharmacological potential of $P$. foetida leaf was supported by all three extracts. These facts rationalize the scientific basis of $P$. foetida being used as a traditional medicine. However, further experiments may help to investigate other pharmacological potentialities of the plant. Also phytochemical screening are suggested to be undertaken to pinpoint the compounds found in each of the extracts and to elucidate the mechanism of such action scientifically.

\section{Acknowledgements}

The authors are grateful to the Department of Pharmacy of East West University.

\section{References}

1. Chauhan K, Patel A, Patel M, Macwan C, Solanki R, Adeshara S. Paederia foetida Linn. As a potential medicinal plant: A Review. Journal of Pharmacy Research, 2010: 3(12), 3135-3137.

2. Rahmatullah M, Mollik MAH, Jilani MA, Hossain MA, Hossain MS, Rahman MM, et al. Medicinal plants used by folk medicinal practitioners in three villages of Natore and Rajshahi districts, Bangladesh. Advances in Natural and Applied Sciences, 2010, 4(2), 132-138.

3. Roy S, Uddin MZ, Hassan MA and Rahman MM. Medico-Botanical Report on the Chakma Community of Bangladesh. Bangladesh Association of Plant Taxonomists, 2008, 15 (1), 67-72. 
4. Alam MA, Azam FMS, Karim MM, Fatema Rehana; Nasima Sharmin, Kalpana MA, et al. In vitro regeneration of Paederia foetida: a widely used medicinal vine in Bangladesh. American-Eurasian Journal of Sustainable Agriculture, 2010, 4(2), 164-169

5. Biswas M., Biswas K., Ghosh, A.K., Haldar, P.K. A Pentacyclic triterpenoid possessing analgesic activity for the fruit of Dregea volubilis. Pharmacogn. Magaz., 2009, 5(19), 90-92.

6. Mia MM, Kadir MF, Hossan MS and Rahmatullah M. Medicinal plants of the Garo tribe inhabiting the Madhupur forest region of Bangladesh. American-Eurasian Journal of Sustainable Agriculture, 2009, 3(2), 165-171.

7. Meera S, Kumar NS and Guptatyam VSSS. Screening of Anti-arthritic, Antiinflmmatory and Analgesic Activity of a Polyherbal Formulation. Int J Pharmacol., 2008, 4(5), 398-402. DOI: 10.3923/ijp.2008.398.402

8. Sharma A, Bhatial S, Kharyaz MD, Gajbhiye V, Ganesh N, Namdeo AG et al. Antiinflammatory and analgesic activity of different fractions of Boswellia serrata. International Journal of Phytomedicine, 2010, 2, 94-99.

9. Subhan N, Alam MA, Ahmed F, Shahid IJ, Nahar L, Sarker SD. Bioactivity of Excoecaria agallocha. Braz J Pharmacogn. 2008, 18, 521-526. DOI: 10.1590/S0102695X2008000400004

10. Nyeem MAB, Alam MA, Awal MA, Mostofa M, Uddin SJ, Islam N et al. CNS Depressant Effect of the Crude Ethanolic Extract of the Flowering Tops of Rosa Damascena. Iranian J. Pharmacol Ther. 2006, 5, 171-174

11. Thippeswamy BS, Mishra B, Veerapur VP, Gupta G. Anxiolytic activity of Nymphaea alba Linn. in mice as experimental models of anxiety. Indian J Pharmacol. 2011, 43, 50-55. DOI: $\underline{10.4103 / 0253-7613.75670}$

12. Braida D, Limonta V, Capurro V, Fadda P, Rubino T, Mascia $\mathrm{P}$ et al. Involvement of kappa-opioid and endocannabinoid system on salvinorin A induced reward. Biol Psychiatry, 2008, 63, 286-292. DOI: $\underline{10.1016 / \text { j.biopsych.2007.07.020 }}$
13. Braida D, CapurroV, Zani A, Rubino T, Viganò $\mathrm{D}$, Parolaro $\mathrm{D}$ et al. Potential anxiolytic- and antidepressant-like effects of salvinorin $A$, the main active ingredient of Salvia divinorum, in rodents. British $J$ Pharmacol., 2009, 157, 844-853. DOI: 10.1111/j.1476-5381.2009.00230.x

14. Chandrashekar KS, Saha S, Subraya PK. Analgesic Activity of Phyllanthus lawii Extract in Swiss Albino Mice. Pharmaceutical Crops, 2011, 2, 8-10. DOI: $\underline{10.2174 / 2210290601102010008}$

15. Diaz, A. and Dickenson, A. H. Blockade of spinal N- and P-type, but not, L-type calcium channels inhibits the excitability of rat dorsal horn neurones produced by subcutaneous formalin inflammation. Pain, 1997, 69, 93100. DOI: $\underline{10.1016 / S 0304-3959(96) 03271-X}$

16. Tanko Y, Kamba B, Saleh MIA, Musa KY, Mohammed A. Anti-nociceptive and antiinflammatory activities of ethanolic flower extract of Newbouldia laevis in mice and rats. Int. j. appl. res. nat. prod. 2008, 1(3), 13-19.

17. Gaertner, M., Muller, L., Roos, J.F, Cani, G, Santos, A.R., Niero, R., et al. Analgesic triterpenes from Sebastiania schottiana roots. Phytomedicine, 1999, 6, 41-44. DOI: 10.1016/S0944-7113(99)80033-6

18. Nishikava H, Hata T, Funakami Y. A role for corticotropin-releasing factor in repeated cold stress-in duced anxiety-like behavior during forced swimming and elevated plu smaze test in mice. Biol Pharm Bull, 2004, 27(3), 352 356. DOI: $\frac{10.1248 / \mathrm{bpb} .27 .352}{\mathrm{~S}, \mathrm{Samanin}}$

19. Millan MJ, Hjo rth S, Samanin R, Schreiber R, Jaffard R, De Ladonchamps B. A novel benzodioxopiperazine ligand of serotonin (\%-5HT)1A receptor: II. Modulation of hippocampal serotonin release in relation to potential anxiolytic properties. J Pharmacol Exp Ther, 1997, 282, 148161 .

20. Khatun $\mathrm{M} \mathrm{H}$, Islam $\mathrm{M} \mathrm{R}$, Mamun $\mathrm{A}$, Nahar L., Luth funnesa, and Islam M.A.U. In Vivo Evaluation of CNS Depressant and Antinociceptive activities of Methanol Extract of Hibiscus sabdariffa Fruits . J. of Appli Scie Rese, 2011, 7(6), 798-804 